\title{
Applying grounded theory to data collected through participatory research on African Independent Churches' liturgical rituals: A comparative study
}

Authors:

Bethel A. Müller

Cas J. Wepener

Affiliations:

${ }^{1}$ Department of Practical

Theology and Missiology,

Stellenbosch University,

South Africa

${ }^{2}$ Department of Practical Theology, University of Pretoria, South Africa

Note:

This article is published in the Section Practical Theology of the Society for Practical Theology in South Africa.

\section{Correspondence to:}

Cas Wepener

Email:

cas.wepener@up.ac.za

Postal address:

Private Bag X20, Hatfield

0028, South Africa

Dates:

Received: 14 Feb. 2011

Accepted: 11 May 2011

Published: 12 Oct. 2011

How to cite this article: Müller, B.A. \& Wepener, C.J. 2011, 'Applying grounded theory to data collected through participatory research on AIC liturgical rituals: A comparative study', HTS Teologiese Studies/ Theological Studies 67(2), Art. \#1034, 8 pages. http:// dx.doi.org/10.4102/hts. v67i2.1034
C 2011. The Authors. Licensee: AOSIS OpenJournals. This work is licensed under the Creative Commons Attribution License.
This article reported on two research projects, the first conducted in the early 1990s and the second, a project currently in progress. In essence, the article was an attempt to compare the theology of African Independent Churches in the two respective periods by making use of a grounded theory approach to their worship services. Significant similarities and differences were identified and reported on.

\section{Introduction}

In this article ${ }^{1}$, two research projects will be described and discussed. Both were funded research projects involving liturgy and preaching in African Independent Churches (AICs). The first project was conducted in the early 1990s and the second is currently running. Juxtaposing the two projects highlights significant similarities and differences, although the research methodologies employed were not identical.

Participatory research and a close-reading technique ${ }^{2}$ were implemented by a research team under Prof. B.A. Müller, with the financial support of the HSRC (Human Sciences Research Council) in the early 1990s. This was applied to 37 tape-recorded services recorded and then transcribed by personnel of NERMIC (New Religious Movements and Independent or Indigenous Churches) under the leadership of Prof. G.C. Oosthuizen. Their research findings were reported in an official document called Skrifgebruik in die Onafhanklike Afrika Kerke (1992). The hypotheses guiding this report were that an analysis of the services and rituals informing the life and practices of these churches was becoming extremely urgent in order to understand the African consciousness expressed in the culture and theology represented by these fast-growing churches (Müller 1992:3). The team realised that the older negative attitude towards these churches, based upon traditional and paternalistic criticism from the developed world, had to be replaced by a more positive approach, as expressed by Barrett (1968), Turner (1967), Oosthuizen (1989), Lamont (1971) and especially Daneel (for details, see Müller 1992:4f) ${ }^{3}$. They realised, with Daneel (1987:19), that the faith of these churches was not expressed in doctrinal concepts, but was 'acted out, danced out' (Turner 1967:82). Robert and Daneel (2007:43) also state in an article that an AIC, in general, 'produces a meagre paper trail'.

In 2008, a partly similar (but also different) research programme on the worship services and other rituals of, amongst others ${ }^{4}$, the Corinthian Church in Phepheni (AIC) commenced with an international research team. Financial support was provided by the NRF (National Research Foundation). The team is interested is establishing whether different 'dimensions' of ritual were 'more adequate' than others, with regard to the generation of social capital (Cilliers \& Wepener 2007:39). The specific overarching research question for the project is: 'How and to what extent does religious ritual contribute to the formation of the kinds of social capital that assists or could assist in alleviating poverty and promoting social development in South African communities?' (Wepener, Swart, Ter Haar \& Barnard 2010:63).

1.This material is based upon work supported by the South African National Research Foundation (NRF) under Grant number 73974. Any opinion, findings and conclusions or recommendations expressed in this material are those of the author and therefore the NRF does not accept any liability in regard thereto.

2.In both research projects, grounded theory, specifically the Heidelberger Method, was applied to transcribed worship services, of which the liturgical material was collected by means of participatory research. According to Pleizier (2010:229), despite the various ways grounded theory can be designed, it usually involves the following steps: 'empirical data is coded, codes are turned into concepts, and concepts are related to hypothetical statements'. The Heidelberger Method was originally designed as a way to analyse sermons by asking very specific questions, namely how the Bible or text was used, what the prevailing concepts of God and of the church embodied in the sermon are and what the socio-ethical implications are. This was very useful in the study of sermons in 1992 . For comparative purposes, we decided to adopt the Method in 2011 .

3.In 1948, Sundkler was still very negative in his evaluation of these churches. In later publications he became more positive. A recent book by Oduro, Pretorius, Nussbaum and Born (2008) has the same aim.

4.In this particular project, a variety of churches representing the South African ecclesial landscape is included, amongst others Reformed Anglican and this one AIC. For an overview of the project, see Wepener et al. (2010:61-82) 
In order to come to grips with the very innovative liturgical material, which is foreign to a person from the developed world, a participatory research method was adopted in this specific study within the overarching research project, which was to analyse five services, all held in Phepheni; all the sermons were transcribed ${ }^{5}$. For this particular contribution, a description of five services is first given ${ }^{6}$. The authors of the article once again used grounded theory to analyse the material and additional interviews were conducted with respondents as deemed necessary. This specific method was adopted here for the sake of comparison with the previous project, although it must be acknowledged that alternative dimensions of rituals could be used, for example those of Lukken (2005:58-70).

\section{The HSRC research performed in 1992 The research programme}

On an aliquot part basis, 37 services were selected that were held in various congregations of AICs in KwaZulu Natal (KZN). Generally speaking, they came from an Apostolic Faith background and to a lesser extent from an Anglican and Episcopal tradition. We will refer later to the effects of this missiological background on their 'faith in action', expressed in their liturgy. The research team was supplied with written transcriptions of these dynamic and communicative liturgical events. Understandably, it was a nearly impossible task to analyse these transcriptions, seeing that oral communicative events have a completely different psychodynamic to that of written documents. It was therefore important to develop a research method that would give access to the real-life and faith worlds implicit in these transcriptions, worlds often so strange to many scholars from the developed world. It had to be a method whereby the team could experience the way these congregations look at life, at faith, what meanings they confer upon, or derive from, these liturgical events. Therefore, it was decided to adopt a method of participant observation, which Lofland called a system of 'interweaving and listening' (1984:13; on this method see Schwartz \& Jacobs 1979:26f). It is a matter of entering sympathetically into the grief and joys of the historical situation of the congregation, often expressed in symbolic language and events. This boiled down to a sensitised close reading of the transcriptions in a concentrated effort to try to understand the belief patterns embedded in and often hidden behind and under the surface of, these transcribed and formalised liturgical events. Only then can theological research come to grips with the rich material and existential meanings expressed in them. It was striking how various rhetorical techniques were used to communicate this meaning, often clad in the 'mists' of the mythical and the symbolic.

\section{The formal liturgical pattern of the services}

In the absence of a fixed pattern, like those in most churches in the developed world, it was extremely difficult to

5.For a description of a typical Sunday worship service in this congregation, see Wepener, Mbaya \& Barnard (in press) and for a special annual service called the Isitisha [the burning of the heifer], see Mbaya (2011).

6 .For more on the use of participatory research in liturgical studies, see amongst others, Johnson (2005), Post (2001), Stringer (1999) and Wepener (2005, 2010). formulate a description of a formal liturgical pattern. Liturgy, in the case of the AIC, is not thought out, but celebrated every Sunday in an innovative and new way; it is rather danced out than described. Faith is not so much articulated in dogmatic concepts as it is lived out. Liturgy is furthermore the product of the creative genius of the leader, acting in unison with the authentic response of the congregation expressed in specific liturgical elements of the service. It was therefore difficult to conceptualise or describe the liturgy in its entirety.

The purpose of the services was clearly to restore and nourish a well-balanced and integrated a quality of life, living in peace with God and all fellow human beings, especially those in the family and in the congregation. By the atoning work of Christ, sinners are saved, cleansed, healed, filled with joy, born again and converted to this blessed life of harmony and peace (see Müller 1992:19-25). The exhortation to strive for this salvation is preached in the sermon, repeated in the hymns and testimonies of fellow-believers, resulting eventually in the confession of sin. In addition to the liturgical exhortations, there was a strong emphasis on teaching the basic tenets of the faith, which has to lead in the end towards a pastoral emphasis in the liturgy, namely to comfort and to console.

In order to help the congregation to share in this inner wholeness, certain rhetorical techniques were implemented in the liturgy. The power of authority resided in the text, the minister and the testimonies delivered in the course of the service. The message is communicated by exhortation, teaching and consolation. In all this a predominantly ethical imperative style was preferred; words used frequently were 'you must, are urged, compelled, we implore, request, ask you', and so forth (see Müller 1992:30). The congregation was exhorted to a continued self-examination, resulting in repentance and conversion. This ethical motif penetrated all elements of the liturgy.

\section{The different elements of the liturgy}

The services usually started with the minister, dressed in liturgical attire, reminiscent of an Anglican background, welcoming the congregation, usually dressed in white robes. A call to worship or a votum follows and a blessing is pronounced.

Daneel regards the reading of Scripture as the 'focal point' of the service (1987:250). Believing that Scripture is in itself the voice of the living God, it represents the basic authority of all that precedes and follows in the service.

The sermon, based roughly on the scriptural text, is central and plays a key role in the liturgy. Quite interesting was the fact that very often more than one sermon was given during the same service, often not clearly related to one another, often interrupted by some member giving testimony or simply by shouts of 'Hallelujah!' But, the sermon holds the service together, acting as an integrating agent, although not always the most important liturgical event. The sermon is a strongly verbal performance, verbose with a strong emotional appeal. 
The reality of sin is referred to in all the services. Great emphasis was therefore placed on the preceding exhortations towards developing a conviction of sin in order to pave the way to the confession of $\sin$. Sin is basically caused by human weakness and disobedience to the instruction contained in Scripture and in the liturgy. Sin is not only spiritual, but also very real in a secular sense, deriving from a self-centred life, slander, corruption, disobedience to parents and ecclesial leaders...

Hymns are an important and indispensable part of the liturgy: in one service hymns were sung 38 times, in another on 33 occasions! They are characterised by praise, supplication and dedication as a response to some event in the liturgy. Drums and circle dancing often accompany the hymnal worship. Choirs are used less often.

Prayers, in the form of individual or communal praise, thanksgiving and intercession are essential parts of every liturgy. Praying the Lord's Prayer occurs nearly in every service.

These prayers are often connected to healing. Physical healing is often performed by a diviner by laying on of hands, whilst the congregation dance in a circle.

On a few occasions, a cleansing service was performed. In the AIC tradition, contact with death or a dead person, or experiencing some bad luck has a fouling effect on a person, who then has to be cleansed before being allowed to share in the service (see Bührman on the pastoral effect of liturgical events) ${ }^{7}$.

There was only one mention of baptism and none of the Eucharist.

\section{The profile of the services, using the four categories of the Heidelberger Method}

\section{The role of Scripture}

Scripture is regarded as the basic authority behind every event in the liturgy. It speaks directly and in an immediate way: it is hardly expounded and explained in terms of its original context, but transferred directly and applied in the actual, existential context of today. The result is that very little exegetical finesse, as is familiar in the Reformed tradition, is practised. The research team called their hermeneutic an associative one, in which texts are not so much explicated, but applied directly, in accordance with the sound of the words and the realities associated with it in the daily life of believers. Texts are therefore instigators of a rhetorically communicative event, supplemented by the rhetorical techniques displayed by the minister. There was a marked preference for narrative texts, supporting the narrative and symbolic idiom in speaking of God, Scripture and the church. Secondly, there was a significant preference for admonishing texts, in line with the exhortative purpose of the whole liturgical performance.

7.See also Wepener (2009a:229-246), in which commensality was used as a tool to measure social capital and which showed that, because of this effect of death on church members, they do not eat at funerals.

\section{The notion, idea or conception of God}

God the Creator is described as the Almighty One, who has more power, also more vigour and life-force [uMoya] than anybody else. He acts in a supreme way in the history of the biblical patriarchs and of Israel, but also in the life of the founders of the church and its history. This creative God is chiefly regarded as Father, the Giver of all good things, the Baba Wethu who helps, guides, cares and protects, even on journeys and in work situations. He rules over their whole life and their destiny. He gives instruction in his Word and the words of the ministers. As the almighty Giver of all blessings, he can be trusted when they bring their need to him. No wonder that the 'Our Father' takes such a central place in the liturgy. He works in close relation to ancestral spirits, acting as protectors against evil. They participate in day-to-day living being a next to God a source of wellbeing, illness being caused by a disturbance of the balance between man and the life-giving spiritual forces (see Bührmann 1984 on this aspect).

The life and work of Christ is the central and guiding force in the entire liturgy and in the life of the church. Salvation in Christ is a comprehensive and all-embracing concept in all the services. He is the Saviour who died on the cross out of love for his people and was resurrected unto eternal life; thereby he takes away their sins and as his children's Friend he knows all their problems and helps to solve them. As their liberator and protector in their daily lives, he does not only take away their sins, but heals them. He restores the harmony in people's lives and one day will take his children to him in heaven. Prior to accepting salvation in Christ, sin must be confessed, amongst others by participating in the ritual of cleansing as mentioned previously.

The Holy Spirit gives power to the believer and is active in the spirit of the ancestors and in charismatic events such as glossolalia. For the rest, little is said about him.

Satan, as counterpart of God, dominates the life of those outside the church, who have to be liberated from the service of Satan by Christ in his battle against the Evil One.

\section{The notion, idea or concept of the church}

The term 'church' is used in a variety ways: for the worship service itself, or as an institutional group, or as a body living in unity and koinonia [community] with one another. The church consists of those who live in obedience to the exhortations and teachings issued in the liturgy. It inherits the Kingdom, entering thereby into the blessed life of peace, mutual love and harmony with one another. There is a strong emphasis on koinonia as the total experience of active love, sharing the needs of the afflicted. In the liturgy, the church is warned against sluggishness in its relationship with God and others, against pretended faith and backsliding. The church and its members must be continually renewed in a spiritual sense. They must become involved in the church, sharing the joys and pains of others and becoming an example in the world. This was the missionary perspective of the different AICs: 
sharing love, especially with those inside the congregation, but also with those outside, irrespective of race and colour.

\section{The social-ethical context of the services (the generation} of social-ethical capital)

There was very little reference to the social-ethical issues of the day. A foreign, privatised ethics was practised, dealing mostly with ethical issues relating to the inside life of the congregation, the practice of harmony with regard to internal mutual relationships, mainly in marriage, inside the family and the congregation (see Müller 1992:30). Respect for older people, for parents and for leaders of the church must be cultivated and financial obligations to others and to the church must not be neglected. In the community of faith, help must be given to those in need, in times of illness and death. But the line between the church and the world is bridged occasionally, when the churchgoer is exhorted to go to all people, irrespective of colour or race. Here, the pastoral emphasis and dynamic displays a missionary perspective. The combination and interaction of both these perspectives is one of the main reasons for the remarkable growth of the AIC.

\section{Some conclusions}

The liturgy functioned primarily in the closed and private space of a small congregation. It was therefore very much an in-group event.

The liturgical elements and innovations display an interesting mixture of two traditions, namely of the more charismatic and spiritualistic background embedded in their missiological history and the African culture expressed in various ways. This is one of the reasons for their dynamic religious appeal and growth.

The low impact of their liturgy on the generation of social capital may also be the result of this mission background: missionary theology and practice were rather more of a spiritualistic and church-orientated nature, with the result that religion was practised in the mission stations, isolated from the community. The ubuntu character of African customs was therefore subdued by this spiritualistic approach.

\section{The NRF research project 2008-2011}

Five services of the Corinthian Church in Phepheni (AIC) were documented and analysed for this case study by a similar method of participant observation and grounded theory. Some provisional results within the framework of the overarching NRF project have been recorded and some also published (cf. Mbaya 2011; Wepener \& Cilliers 2007; Wepener 2009a; Wepener et al. 2010; Wepener \& Barnard 2010; Wepener, Mbaya \& Barnard in press). In this second section, a provisional formal liturgical pattern will once again be described first, followed by a liturgical profile in accordance with the Heidelberg Method of analysis.

\section{The formal pattern}

The same difficulty as in 1992 was experienced in describing a formal pattern, because there is no descriptive and theologically worked out plan for the liturgy. Liturgy is part of an innovative and creative process, often dictated by the actual situation of the service. Liturgy is played as a game of faith, is danced out in practice, although the participatory observation did, in fact, discern a pattern over time as described in Wepener, Mbaya and Barnard (in press). This pattern basically consists of the elements of:

- welcoming rite

- invocation

- prayer

- Apostolicum

- the Lord's Prayer

- Scripture readings

- sermons

- National Anthem

- healing rites

- burning of incense

- sharing of visions

- blessing.

All these elements are connected by the circle dance, accompanied by singing and the playing of musical instruments.

The purpose of these services was very much the same as in 1992. It consisted of bringing the participants to wholeness, an experience of the fullness of the life. Sin and Satan are regarded as disrupting this wholeness, which must be restored by Christ and people following his example. Despite this fact, arising from the use of grounded theory with regards to the transcribed services, other qualitative methods such as interviews and focus groups used in the church within the broader project also confirmed this finding. Informal discussions with members regarding why they worship specifically in this church and not another usually has to do with healing or experiences of being healed in this church's worship ${ }^{8}$.

Rhetorically, the service calls on the congregation to obey Scripture and the preached word. Again, the imperative abounds, but this time it was more rooted in the indicative, for example 'because God loves you ... you must give yourself' or 'because you are his family ... keep his commandments and instructions'. There is a call to action, to do what Jesus did; this is new and different compared to the 1992 research. Further research is needed to inquire about the reasons for this.

The elements of the service will be described in what follows (cf. also Wepener, Mbaya \& Barnard in press). We will, however, focus only on those most relevant to our study.

The service starts with a welcome (even a welcome dance for visiting researchers). These services are in actual fact very 8.In this regard, see also the research on eating and drinking in this congregation (Wepener 2009a). 
welcoming (Wepener \& Barnard 2010:8). This is followed by a kind of invocation, invoking the Holy Spirit to be active in the service, also invoking the spirit of the founder Johannes Richmond (Wepener \& Barnard 2010:9). The services are conducted by an ordained minister, assisted by members of the congregation doing the Scripture reading, giving testimony, sharing a vision or dream, assisting with the healing and cleansing rituals.

The reading of Scripture takes a central place in the liturgy. More than one reading takes place in the same service (see also Wepener \& Barnard 2010:1). Great respect is shown towards Scripture and the congregation raises their hands every time it is read.

Following the Scripture reading, the sermons form an important element of the whole service, giving it an integrated structure. More than one sermon is quite common; everybody is allowed to preach or give their testimony, which is part of the sermon but not necessarily integrated with it, like the manifold sermons themselves. Most sermons, however, are delivered by Rev. Dingaan, the leader priest of the congregation and sometimes by one of the other two priests, one of whom is a woman.

Confession of $\sin$ is referred to in the sermon, but there was very little sign of it being a separate liturgical element, as it was in 1992.

Hymns, accompanied by drums and circle dances formed a strong and essential part of all the services.

The singing is often accompanied by prayer, often accompanied by chanting or with congregants in a kneeling position. Prayers can be very long, taking up to 25 minutes. An interesting custom is that the door of the hut acting as the 'church building' is closed every time a prayer is offered; is this form a liturgically sanctifying element? Prayers are meant to invoke the Holy Spirit and the spirit of the forefathers to become active, whereas the circle dance may be a sort of epiclesis, which prepares the congregation to listen to the Word, but also to invoke the Spirit for other liturgical elements such as healing rites.

Healing always forms part of the service (Wepener, Mbaya \& Barnard in press).

Members of the congregation who have become contaminated through contact with death or other unfortunate situations have to be cleansed before they are allowed to attend a service (cf. Wepener, 2009a). This takes place as a ritual, very close to our modern day psychotherapeutic practices (see on this Bührman 1984). Many of the rituals observed and described are also reminiscent of practices described in the Book of Leviticus; however, there seem to be various influences that inspire these cleansing practices. Some of these include Xhosa traditions, rites encountered in Leviticus and unique Corinthian Church rituals prescribed by the founder; also the fact that the founder's father was a Muslim means that much Islamic symbolism is evident in the Christian church.

Baptism is a very important part of the liturgy, acting as a ritual whereby members are presented to God as his children. However, apart from baptism, there are also other water rituals such as a ritual that involves jumping into the river at the beginning of a new year.

A blessing is given at the end of the service and the researchers are always invited to a meal afterwards.

\section{The profile of the service}

\section{The role of Scripture}

Scripture is regarded as the basis of God's revelation to his people. He speaks his Word in a nearly Barthian way. To quote Rev. Dingaan on the matter, 'the Spirit makes God's Word alive in our congregation. The Bible is more than a book; it is the living Word of the Spirit'. A formal exegesis and hermeneutic is not practised; Scripture is expounded in a very direct way. The words of the text are made directly applicable to the daily life of the listening congregation. Even allusions to the donkey used by Christ in the entry to Jerusalem is spiritualised to manifest the humility of Christ. As God's revelation, Scripture must be proclaimed as the basis of all Christian life and faithful living. This proclamation is carried out in an emphatic instructive and imperative mode.

Superficially, there seems to be a great similarity with the findings of the 1992 research: in the preparation of the sermon very little, if any, objective exegesis is performed; apart from a broad spiritualising hermeneutic, there seems to be a complete lack of a more scientific hermeneutical consciousness. It is believed that biblical texts are read and understood under the direct inspiration of the Holy Spirit and then applied directly without use of interpretative skills. The application seems to be governed by strong legalistic emphases.

On closer inspection, however, there is a very distinct use of Scripture, relating to the preacher's general knowledge and understanding of biblical texts in line with theological tradition. This is enriched by a distinct Christocentric hermeneutic, whereby texts are interpreted christologically, specifically in relation to sin. Furthermore, texts are interpreted in terms of the concrete needs in the congregation and in the community in general. We can thus speak of a distinct pastoral hermeneutic.

Note the interesting use of the circle dance in the preparation of the service and throughout as a means to hear the Word correctly. It is regarded as a means to invigorate the Holy Spirit and the spirit of the founder to guide the use of Scripture in the service. We can call this a form of epiclesis, which is an important element of the Reformed liturgical tradition in relation to the sermon and in the Roman Catholic tradition in relation to the Eucharist, but it seems in this AIC in relation to all the different liturgical elements. 


\section{The focus of the liturgy}

As was explained previously, the services focused on bringing the participants into the wholeness of a balanced life and the experience of the fullness of it, a fullness restored by Christ in the people following his example. Forgiveness of sin is central in the liturgy, after being warned against the many evils in the congregation and in society.

The service calls on the congregation to obey Scripture and the proclaimed Word. On the surface this seems to be legalistic, but looking more closely, it becomes evident that this is rooted in the indicative, as previous examples prove.

The service is very pastoral in its approach. It wants to, amongst other things, give hope by emphasising giving love and help to people in need. This pastoral dimension is nourished by the total liturgical celebrations of the Sunday. Here, homiletics is rooted in the total liturgy, a valuable principle to be followed by all churches! When we asked Rev. Dingaan what the most important theme to preach about is, he answered without hesitating that it is indeed hope.

The sharing of the blessing is an important part of the liturgy as a counter to any form of legalism.

Teaching and commissioning of believers in the office of proclaiming the message of salvation is important in the sermons, but is also ritually acted out ${ }^{9}$. This is a basic Reformed principle, echoed in the homiletic emphasis on the building up of the church and nurturing its identity (see Campbell 1997:221f).

\section{The notion or idea of God}

God, as Creator, is revered as the almighty one, protector and lawgiver.

Christ, as Saviour, forms the central part of the believer's life; soteriology becomes the essence of all proclamation. As Saviour, he is our example. Believers are called to 'do what Jesus did just as Jesus did'. As our Friend, he is the source of the fullness of life.

The whole service is an action of the Holy Spirit, who makes God's Word alive in the congregation. Life is essentially regarded as spiritual. All elements of the liturgy derive their efficacy from the spiritual power, thereby becoming vehicles of this power [amandla]. However, the work of the Spirit is also understood in a broader sense in as far as traditional rituals connected to the ancestral cult are still performed and members are also urged to adhere to these customs (for example, the baptism sermon and the so-called Ladi-service that must first be performed in members' homes). The Spirit is also not identical to the spirit of the founder, although it seems as if there is some sort of cooperation.

9.During the annual Isitisha [the burning of the heifer] service in Mlazi several hours are spent on initiating and then commissioning members for service.

\section{The idea or notion of the church}

The Church is regarded as the family of God, a people of God, who are a community of love and fellowship. Love and fellowship are the 'most important thing in life', based on 'God is love'. The God who receives them as his children stimulates a sense of belonging to God and to one another. He makes them into a community of support, accepting one another, sharing their needs.

The role of baptism is very important, as through it God receives them into his family and thereby structures a bond between him and them, so that they can obey and care for one another.

Interesting is the role of the Apostolicum. Do they want to express a relationship with the tradition of the Church through this?

\section{The idea or notion of the secular context}

The preacher himself says that he is not much interested in socio-political issues. However, in the message of the sermon, in the embodiment of the Word in the liturgy and in the emphasis on being a community of faith, this faith is not so much expressed and manifested in sound dogma, but in faithful living in both the congregation as well as in the secular context. It is also noteworthy that the National Anthem is often sung during worship services, an element that could not be present in the 1992 research because the National Anthem was only a product of the National Assembly after $1994^{10}$. As a hymn, it did also not appear in the collected data from the first project.

The sermons give due attention to specific socio-political issues, especially those existing within the community of believers: individuals in trouble, the preacher telling the congregation who are the people in need, encouraging the giving of gifts... This is all part of a sound diaconological perspective on the preaching event. The annual Isitshisa [burning of the heifer] service is not part of this case study, but it could be noted that at that service, members from this congregation collect food and money, which is then donated to poor blind people.

As a community of love, they are called to a life of charity, thereby becoming the source of creating and generating social capital.

In the secular world, life is incomplete, full of problems in families and amongst friends; there are people going hungry and who are without work. Robbery and violence exist, evil multiplies and 'bad people' who are bewitched cause trouble in and outside the church. In dealing with this, the congregation is called to its missionary obedience to the guidance of the Spirit. This is clearly manifested in their outreach on trains, in buses and in their context in general.

10.In the same period that this development seems to have occurred in AIC worship much research have been carried out on the theme of the role of worship in the
South African socio-political context. See, for example, De Klerk (2001), Müller South African socio-political context.
$(2006,2007)$ and Wepener (2009b). 


\section{Conclusion}

On the surface, there seems to be many similarities between the general focus of the services, especially in the use of Scripture in the sermons (see the description of the profile of the 1992 services and the description on the 2007-2010 services earlier). In both cases, there is no fixed liturgical pattern: liturgy is not thought out, but celebrated; there is an absence of exegetical and interpretational skills; a form of moralistic and legalistic proclamation abounds; the marked influence of their mission background and its mission theology was obvious. On the surface, it seems as if very little theological development has taken place in the interim.

On closer inspection, a very remarkable theological development can be registered. What is noticeable, is a move away from the charismatic, pseudo-pietistic, as well as Anglican approach to a more Reformed one. This is clearly evident in the role played by the Scripture as Word of God, in an almost Barthian sense! The Word and especially its proclamation are regarded as the primal basis of belief and faithful living. Reminiscent of the Reformed emphasis on doxology in the relation to God is the reverence of the congregation when Scripture is read and in times of prayer (see Wainwright 1980). The use of the circle dance as a specific form of the Reformed epiclesis was evident. The Christological emphasis in the services reminds us of Calvinistic and indeed, the whole of the Reformed tradition. The imperative based on the indicative was obvious, especially on closer inspection. The use of an ordained minister in the preaching and the emphasis on the office of believers is characteristic of Reformed doctrine. One reason for this state of affairs, however, could be the fact that the minister of Phepheni was indeed influenced by his contacts with Dr Danie van Zyl at Sokhanya Bible School.

In comparison with 1992, a much stronger ecclesiological emphasis was noticeable. A clear example can be seen in the practice of baptism as incorporation into the family of God and the fellowship of believers. Also, the use of the Apostolicum is evidence of this, a clear sign to us that the congregation wants to show its affiliation with the tradition of the church at large. The pastoral emphasis and the role of the communio sanctorum [community of saints] as an anchor in a very unstable world, especially experienced in the suburbs, is indicative of the role of the church today in its diaspora! The role of cleansing is reminiscent of the necessity of confession and forgiveness of sins, advocated by the early church, prior to participating in the liturgy and sharing community?

The role of the Spirit infusing all elements of life was much more emphasised in 2010 than in 1992.

In 1992 the services were held in the open air, outside of buildings. In 2010 a hut was used as the liturgical space where the congregation met.
The emphasis on being a community of love and charity reminds us of the often forgotten Reformed emphasis on the communio sanctorum [community of saints] as the secular expression of the identity of the church.

It seems as if the AICs have been more and more open to theological influences, or in any event this particular Corinthian congregation. This may also be a consequence of the many positive evaluations of them, accepting them as part of the body of Christ.

Thus, although on the surface there seems to be very little difference regarding the data collected in the 1992 and in the 2008 projects, a closer look reveals new theological influences, whilst still strongly adhering to traditional AIC theology.

\section{Acknowledgements Competing interests}

The authors declare that they have no financial or personal relationship(s) which may have inappropriately influenced them in writing this article.

\section{Authors' contributions}

The two authors co-operated closely in the research process and writing of the article. B.A.M. was the leader of the 1992 project and conducted most of the field research then and C.W. is the current NRF project leader and conducted all the field research in that project that was used in this article. The two authors wrote this article together.

\section{References}

Barrett, D.B., 1968, Schism and Renewal in Africa, Oxford University Press, London. Bührman, M.V., 1984, Living in Two Worlds, Human \& Rosseau, Cape Town.

Campbell, C.L., 1997, Preaching Jesus: New directions for Homiletics in Hans Frei's Postliberal Theology, Eerdmans, Grand Rapids, MI.

Cilliers, J. \& Wepener, C., 2007, 'Ritual and the Generation of Social Capital in Contexts of Poverty: A South African Exploration', International Journal of Practical Theology 11, 39-55. http://dx.doi.org/10.1515/IJPT.2007.4

Daneel, M.L., 1987, Quest for Belonging, Mambo Press, Gwero.

De Klerk, B.J., 2002, 'Liturgie, transformasie en die Afrika Renaissance', in M. Barnard \& N. Schuman (reds.), Nieuwe wegen in de liturgie: De weg van de liturgie - een vervolg, n.p., Meinema, Zoetermeer.

Johnson, C.V., 2005, 'Researching Ritual Practice', Studia Liturgica 35(2), 204-220

Lamont, V. (ed.), 1971, 'And some fell on good ground', Risk 7(3), 1-62.

Lofland, J. \& Lofland, L.H., 1984, Analyzing Social Settings: A Guide to Qualitative Observation and Analysis, Wordsworth, Belmont, MA.

Lukken, G., 2005, Rituals in Abundance: Critical Reflections on the Place, Form and Identity of Christian Ritual in our Culture, Liturgia Condenda 17, Peeters, Leuven.

Mbaya, H., 2011, 'The socio-practical dimensions of isitshisa in the Corinthian Church of South Africa', HTS Teologiese Studies/Theological Studies 67(2), Art. \#930, 8 pages. http://dx.doi.org/10.4102/hts.v67i2.930

Müller, B.A., 2006, “'Liturgie as agent in transformasieprosesse/Liturgy as agent in Transformation Processes"', Nederduits Gereformeerder Teologiese Tydskrif 47(3\&4), 600-608

Müller, B.A., 2007, 'Liturgy at the edges: Between doxology and domestication', Scriptura 96, 441-452.

Müller, B.A., 1992, Skrifgebruik in die Onafhanklike Afrika Kerke: 'n Hermeneutiese Ondersoek na die Skrifgebruik en Kommunikasieproses in 'n Steekproef, RGN, Pretoria.

Oduro, T., Pretorius, H., Nussbaum, S. \& Born, B., 2008, Mission in an African way: A practical introduction to African Instituted Churches, CLF, Wellington.

Oosthuisen, G.C., Edwards, S.D. \& Wessls, W.H. (eds.), 1989, Afrochristian Religion and Healing in Southern Africa, Edwin Mellen, Leviston. 
Pleizier, T., 2010, 'Religious Involvement in Hearing Sermons: A Grounded Theory Study in Empirical Theology and Homiletics', Summary of Dissertation, Jaarboek voor liturgie-onderzoek 26, 227-232.

Post, P.G.J., 2001., '“Introduction and application: Feast as a key concept in a liturgical studies research design'", in P.G.J. Post et al. (eds.), Christian Feast and Festival: The Dynamics of Western Liturgy and Culture, pp. 47-77, Peeters, Leuven.

Robert, D.L. \& Daneel, M.L., 2007, 'Worship among Apostles and Zionists in Southern Africa', in Christian Worship Worldwide: Expanding Horizons, Deepening Practices, ed. C.E. Farhadian, The Calvin Institute of Christian Worship Liturgical Studies Series, Grand Rapids, MI.

Schwartz, H., \& Jacobs, J., 1979, Qualitative Sociology: A Method to the Madness, Free Press (Macmillan), New York.

Stringer, M.D., 1999, On the Perception of Worship, Birmingham University Press, Birmingham.

Sundkler, G.M., 1948, Bantu Prophets in South Africa, Oxford University Press, London.

Turner, H.W., 1965, Profile through Preaching, IMC Research Pamphlet 13, Edinburgh House, Edinburgh.

Wainwright, G., 1980, Doxology: The Praise of God in Worship, Doctrine and Life, Epworth Press, London.
Wepener, C. \& Barnard, M., 2010, 'Entering the Field. Initiating Liturgical Research in an AIC', Acta Theologica 30(2), 192-210.

Wepener, C., Mbaya, H. \& Barnard, M., (in press), 'Worship in the Corinthian Church of Zion in Phepheni Part 1. A Descriptive Exploration of Sunday Worship', Studia Liturgica 41(2).

Wepener, C.J., 2009a, 'Snert. Ritual-liturgical measurements and recipes for social capital', Jaarboek voor rituele- en liturgische studies 25, 229-246.

Wepener, C.J., 2009b, From fast to feast: A ritual-liturgical exploration of reconciliation in South African cultural context, Liturgia Condenda 19, Peeters Pers, Leuven.

Wepener, C., Swart, I., Ter Haar, G. \& Barnard, M., 2010, 'The Role of Religious Ritual in Social Capital Formation for Poverty Alleviation and Social Development. Theoretical and Methodological Points of Departure of a South African Exploration', Religion and Theology 17, 61-82. http://dx.doi. org/10.1163/157430110X517924

Wepener, C.J., 2010, 'Liturgical research in a changing South African socio-cultural (liturgical) landscape: Challenges and opportunities for method and theory', in I. Swart et al. (eds.), Religion and Social Development in Post-Apartheid South Africa: Perspectives for Critical Engagement, n.p., SUN Press, Stellenbosch.

Wepener, C.J., 2005, 'Researching Rituals. On the use of participatory action research in liturgical studies', Praktiese Teologie in Suid-Afrika 20(1), 109-127. 